УДК: 636.09:614.48:578

doi: $10.36359 /$ scivp.2019-20-2.24

\title{
ВИВЧЕННЯ СТІЙКОСТІ АНТИБІОТИКОРЕЗИСТЕНТНИХ ШТАМІВ $S$. AUREUS ДО ДЕЗІНФІКУЮЧИХ ЗАСОБІВ 3 РІЗНИМИ ДІЮЧИМИ РЕЧОВИНАМИ
}

\author{
T. О. Гаркавенко ${ }^{1}$ канд. вет. наук, ст. наук. сn., \\ Т. Г. Козицька ${ }^{3}$, пошукувач ${ }^{1}$,

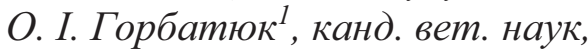 \\ В. Л. Коваленко ${ }^{2}$, д-р вет. наук, професор
}

${ }^{1}$ Державний науково-дослідний інститут з лабораторної діагностики і ветеринарносанітарної експертизи, вул. Донецька, 30, м. Київ, 03151, Україна

${ }^{2}$ Державний науково-контрольний інститут біотехнології і штамів мікроорганізмів, вул. Донецька, 30, м. Київ, 03151, Україна

У статті подані дослідницькі матеріали з визначення чутливості польових ізолятів S. aиrеиs до антибіотиків та встановлений рівень їхньої резистентності стосовно всіх застосованих препаратів. 3 а представленими даними виявлена поліантибіотикорезистентність штамів золотистого стафілокока з рівнем стійкості від 11,1 до 88,9\% з огляду на 18 видів застосованих антибіотиків, в т.ч. $і$ з штами МRSA. B матеріалах статті наведені дані досліджень з вивчення дії деяких дезінфікуючих засобів на поліантибіотикорезистені штами збудника. В статті приведені факти того, щуо виявлені штами MRSA проявляли особливу стійкість до дослідних дезінфектантів у певних їхніх робочих концентрачіях, які не знешкоджували збудника. Виявлені MRSA штами проявляли резистентність до більшості антибіотиків та були стійкими до дії певних концентрацій дезінфікуючих засобів, щя, ймовірно, пов'язане з формуванням спільного фенотипічного механізму стійкості до дії антибактеріальних препаратів і засобів.

Ключові слова: S. AUREUS, MRSA, ШТАМИ, АНТИБІОТИКИ, РЕЗИСТЕНТНІСТЬ, ДЕЗІНФЕКТАНТИ, ПОЛЬОВІ ІЗОЛЯТИ, ФЕНОТИПІЧНИЙ МЕХАНІЗМ СТІЙКОСТІ.

Аналіз літературних даних показав, що наразі закономірність формування набутої резистентності до антибіотиків, дезінфікуючих i антисептичних препаратів i засобів у мікроорганізмів і їхнє поширення вивчені не достатньо. Відомо, що антибіотики діють на мікроорганізми диференційовано, проникаючи всередину мікробної клітини і викликаючи іï загибель через зв’язування зі специфічною «мішенню». Це дозволяє антибіотику вибірково діяти і пригнічувати бактеріальну популяцію. Дія антисептиків і дезінфікуючих засобів не $\epsilon$ вибірковою, залежить від їхнього хімічного складу і направлена у кількох напрямках, наприклад, викликаючи деструкцію клітинної стінки і цитоплазми; взаємодіючи 3 ферментами, які контролюють життєдіяльність мікробних клітин; руйнуючи рибосоми; порушуючи синтез білка і т. ін., що призводить до загибелі бактерій. За таких обставин у окремих штамів або особин у штамах патогенних мікроорганізмів формується набута резистентність, що характеризується властивістю бактеріальних клітин зберігати свою життєдіяльність за дії на них антимікробних препаратів і засобів через формування нової генетичної інформації або ж зміни власних генів. Особливістю набутої резистентності є те, що вона не зникає і може бути повністю елімінована лише у випадку повної загибелі усіх бактеріальних клітин такої популяції [1-3].

${ }^{3}$ Науковий керівник - Т. О. Гаркавенко, канд. вет. наук 
Існує безліч гіпотез, проте до сьогодні ще не встановлено чи є різними і чи зв’язані між собою гени, що відповідають за видову та набуту резистентність до антибіотиків, антисептиків і дезінфікуючих засобів. Наразі лише накопичуються дані про загальні генетичні механізми стійкості мікробних клітин до антибіотиків, дезінфікуючих засобів і антисептиків, зокрема зниження проникності мікробної стінки і активне виведення протимікробних речовин із клітин бактерій, які дозволяють їм витримувати значно вищі їх концентрації, порівняно 3 культурами клітин збудників, у яких такі механізми відсутні [4-7]. На базі одержаних результатів досліджень низка науковців прогнозує, що у клінічно значущих ізолятів бактерій, які володіють полірезистентністю до антибіотиків, існування сумісних механізмів резистентності і до антисептиків і до дезінфікуючих засобів $[8,9]$.

Відомо, що у популяціях бактерій розповсюджені екстрахромосомні фактори спадковості - плазміди $[8,9]$. За розмірами вони менші від хромосомної ДНК і з нею не пов'язані, оскільки відтворюються без ії участі. Гени, які переносять плазміди, допомагають клітинам-носіям у виживанні за несприятливих умов зовнішнього середовища. Найбільш розповсюдженими у бактеріальних популяціях $є$ плазміди антибіотикорезистентності (Rплазміди), які несуть гени, що кодують синтез речовин і є деструкторами антибіотиків (беталактамаз, тощо) та захищають бактеріальні клітини від дії зовнішніх несприятливих факторів [10-13].

$S$. aureus є одним із головних антибіотикорезистентних патогенів бактеріального походження, який дуже швидко пристосовується до селективного тиску антибіотичних препаратів. За останні 10 років інфекції, викликані $S$. aureus, виявилися суспільною проблемою, оскільки і епідеміологічна і епізоотична ситуації ускладнюються через зростання частоти виділення ізолятів стафілококу, резистентних до оксациліну (метициліну) - MRSA, які є стійкими і до всіх ß-лактамних антибіотиків та інших класів антимікробних препаратів. Вважають, що підвищення стійкості стафілококів до антибактеріальних, антисептичних препаратів i дезінфікуючих засобів пов'язане із неконтрольованим застосуванням їх у популяції людей, в популяції тварин, поширення резистентних штамів між людьми і між тваринами або передача резистентних штамів від тварин до людей (або навпаки) через безпосередній контакт та через споживання продукції тваринницької галузі.

Отже, дослідження фенотипічних і генотипічних механізмів формування набутої стійкості до антимікробних засобів та пошук їхніх спільних генетичних механізмів щодо такої стійкості є актуальними питаннями сьогодення.

Тому, метою нашої роботи було провести дослідження резистентності польових ізолятів $S$. aureus до антибіотиків та до дезінфікуючих засобів з різними діючими речовинами для виявлення штамів збудника, стійких до обох антимікробних препаратів і засобів.

Матеріали і методи. За виконання дослідницьких робіт були використані 7 польових ізолятів S. aureus (штами «18»; «21/61»; «22/62»; «23/53»; «27»; «28»; «30/60»), одержаних із зразків сировини (молоко коров'яче) і продукції тваринного походження (масло, копчене м'ясо) та об'єктів довкілля (змиви з поверхонь), відібраних на переробних підприємств різних областей України та штам S. aureus ATCC 25923 в якості контролю.

Для проведення досліджень з визначення чутливості штамів до антибіотиків дослідні і контрольну тестову культуру висівали на кров'яний агар (КА), культивували в умовах термостата упродовж 24 год за температури $37{ }^{\circ} \mathrm{C}$. Після закінчення інкубації виготовляли мікробні суспензії у концентрації $0,5 \times 10^{9}$ м.кл./см ${ }^{3}$ за оптичним стандартом каламутності МакФарланда (stardand 0,5) для постановки досліду. Далі розливали мікробну суспензію кожного штаму на чашки з МПА в об'ємі по $0,1 \mathrm{~cm}^{3}$, рівномірно розтирали шпателем по всій поверхні агару та через 15 хв накладали диски з відповідними за EUCAST антибіотиками. Облік результатів проводили через 24 год інкубування посівів в умовах термостату за тих же режимів [13]. 
Перед дослідженнями на стійкість польових штамів стафілококів до дослідних дезінфектантів, були проведені підготовка та дослідження тест-культури S. aureus ATCC 25923 на відповідність основним типовим властивостям та стійкість до еталонних дезінфікуючих засобів - 0,2 \% розчину хлораміну (експозиція 15 хв); 3,0\% розчину перекису водню (експозиція 20 хв); $0,06 \%$ розчину глутарового альдегіду (експозиція $10 \quad$ хв); $0,025 \%$ розчину алкілдіметілбензіламонію (АДБАХ-експозиція 10 хв), після дії яких тестова культура повинна загинути. Тестова культура $S$. aureus ATCC 25923 відповідала всім необхідним вимогам. Після цього всі дослідні штами стафілококів та тестова культура $S$. aureus ATCC 25923 були висіяні на МПА та були культивовані упродовж 24 год за температури $37{ }^{0} \mathrm{C}$. Із одержаних добових агарових культур виготовляли суспензії у концентрації $2,0 \times 10^{9}$ м.кл./ $\mathrm{cm}^{3}$ за оптичним стандартом каламутності МакФарланда (stardand 2) та проводили дослідження [14, 15].

Для проведення досліджень 3 вивчення впливу дезінфектантів на польові ізоляти S. aureus в якості останніх застосовували дезінфікуючі засоби вказані в таблиці 1.

Таблиияя 1

Дезінфікуючі засоби, використані у дослідах

\begin{tabular}{|c|c|c|c|}
\hline $\begin{array}{c}\text { Номер дезінфікуючого } \\
\text { засобу, який } \\
\text { застосовувався }\end{array}$ & Вміст діючих речовин згідно листівки-вкладки & $\begin{array}{c}\text { Концентрації, } \\
\text { \% }\end{array}$ & $\begin{array}{c}\text { Експозиція, } \\
\text { хв. }\end{array}$ \\
\hline № 1 & $\begin{array}{l}\text { В } 100 \text { мл препарату: Бензалконія хлорид - 5,0 г, } \\
\text { Глутаровий альдегід - 10,0 г; } \\
\text { Формальдегід - 14,8 г. }\end{array}$ & 0,$25 ; 0,5 ; 1,0$ & 30 \\
\hline № 2 & $\begin{array}{l}\text { В } 1 \text { кг препарату: } \\
\text { Гліоксалевий альдегід - 5,0 г; } \\
\text { Глутаровий альдегід }-115,0 \text { г; Бензалконій хлорид } \\
\text { - 240,0 г; } \\
\text { Додецилдиметиламоній хлорид -5,0 г. }\end{array}$ & 0,$05 ; 0,25 ; 0,5$ & 30 \\
\hline № 3 & $\begin{array}{l}\text { Препарат містить діючі речовини (\%): } \\
\text { Глутаровий альдегід - } 8 \text { \%; } \\
\text { Гліоксалевий альдегід - } 8 \text { \%; } \\
\text { Четвертинні амонієві сполуки - } 20 \text { \%; } \\
\text { Полігексаметиленгуанідин гідрохлорид - } 1 \text { \%. }\end{array}$ & 0,$05 ; 0,25 ; 0,5$ & 30 \\
\hline
\end{tabular}

Результати й обговорення. Аналіз результатів досліджень на чутливість до антибіотиків тестової культури $S$. aureus ATCC 25923, яку використовували в якості контролю поживного середовища і антибіотиків, підтвердив її відповідність вимогам EUCAST, оскільки діапазони діаметрів зон затримки росту знаходився у визначених межах до кожного виду застосованих антибіотиків, що за подальших досліджень польових ізолятів засвідчувало вірогідність одержаних результатів (табл. 2). Результати досліджень показали, що серед досліджених польових ізолятів золотистих стафілококів лише у $S$. aureus штам «21/61» була виявлена чутливість до всіх застосованих антибіотиків. Найвищий рівень резистентності був притаманний $S$. aureus штам «28», оскільки із застосованих 18 видів антибіотиків, збудник був чутливим лише до гентоміцину і лінезоліду, що складало 88,9 \% резистентності щодо всіх застосованих препаратів. Висока резистентність спостерігалася у $S$. aureus штам «18» і штам «30/60» так, як ізоляти були резистентними до 11 iз застосованих препаратів (61,1 \% резистентності). Інші виділені ізоляти $S$. aureus проявляли резистентність в діапазоні від 11,1 до 27,8 \% серед застосованих антибіотиків. Слід зауважити, що $S$. aureus штами «18», «28» і «30/60» були резистентними до цефоксітіну. За даними EUCAST, якщо у штамів $S$. aureus виявлена резистентність до цефоксітіну, то їх вважають резистентними до оксациліну (MRSA-стафілококи) i антибіотиків клоксациліну, диклоксациліну, флуклоксациліну, нафциліну та антибіотиків групи цефалоспоринів.

Таким чином, для проведення досліджень з вивчення питань щодо виявлення спільних фенотипічних механізмів стійкості до антибіотиків і дезінфікуючих засобів були обрані 
ізоляти S. aureus 3 високим (штам «28»), середнім (штами «18» і «30/60»), низьким (штами «22/62», «23/53» і «27») рівнями резистентності та нерезистентний (штам «21/61»).

Таблиияя 2

Результати досліджень на чутливість до антибіотиків польових ізолятів $S$. aureus; n=7, мм

\begin{tabular}{|c|c|c|c|c|c|c|c|c|c|c|c|c|c|c|c|c|c|c|c|c|c|c|c|c|c|c|}
\hline \multirow[b]{2}{*}{ № } & \multirow[b]{2}{*}{$\begin{array}{l}\text { Штами } \\
S . \text { aureu } \\
s\end{array}$} & \multirow[b]{2}{*}{ 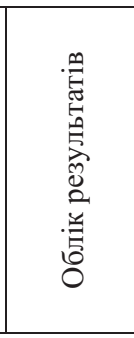 } & \multicolumn{23}{|c|}{ Назва антибіотиків } & \multirow[b]{2}{*}{ 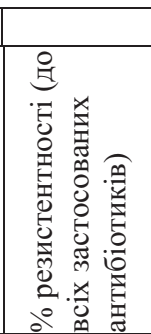 } \\
\hline & & & 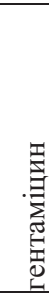 & 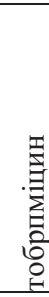 & 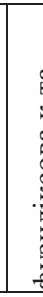 & & . & & 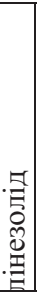 & 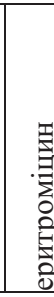 & & 蒗 & 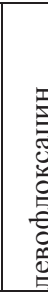 & & 题 & 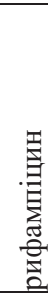 & 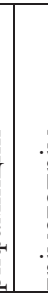 & 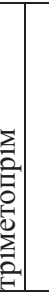 & 罯 & 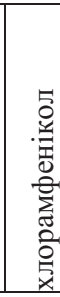 & 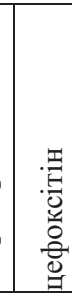 & 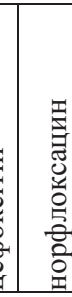 & 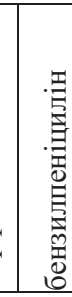 & 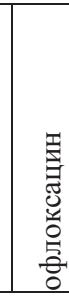 & 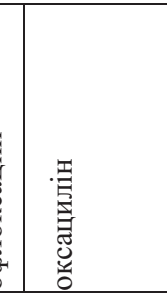 & \\
\hline \multicolumn{27}{|c|}{ Контроль (тестова культура ) } \\
\hline \multirow[t]{3}{*}{1} & \multirow{3}{*}{ 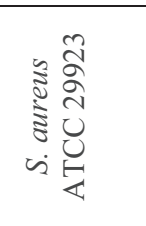 } & \begin{tabular}{|l} 
3a \\
EUCAST
\end{tabular} & $\begin{array}{l}19- \\
25\end{array}$ & $\begin{array}{l}20- \\
26\end{array}$ & $\begin{array}{c}26 \\
32\end{array}$ & & 32 & $\begin{array}{r}21- \\
27\end{array}$ & & $\begin{array}{l}23- \\
29\end{array}$ & $\begin{array}{l}18 \\
2\end{array}$ & & \begin{tabular}{|l|}
$23-$ \\
29
\end{tabular} & $\begin{array}{c}21 \\
27\end{array}$ & $\begin{array}{l}3 \\
3\end{array}$ & $\begin{array}{l}0- \\
36\end{array}$ & $\begin{array}{r}22- \\
28\end{array}$ & $\begin{array}{c}23 \\
29\end{array}$ & & $\begin{array}{l}20- \\
28\end{array}$ & $\begin{array}{c}24- \\
30\end{array}$ & $\begin{array}{l}18- \\
24\end{array}$ & \begin{tabular}{|l|}
$12-$ \\
18
\end{tabular} & \begin{tabular}{|l|}
$21-$ \\
27
\end{tabular} & \begin{tabular}{|c|}
$* / 3 а$ \\
чутливістю \\
до цефок- \\
сітину
\end{tabular} & \\
\hline & & облік & 22 & 21 & 21 & & 26 & 27 & & 23 & 18 & 2 & 5 & 27 & 30 & & 22 & 2 & \begin{tabular}{l|l}
44 & 2
\end{tabular} & 25 & 24 & 23 & 31 & 27 & $* / 25$ & \\
\hline & & оцінка & $\mathrm{Y}$ & $\mathrm{Y}$ & $\mathrm{4}$ & & Ч & 4 & & $\mathrm{Y}$ & $\mathrm{u}$ & & $\mathrm{Y}$ & $\mathrm{Y}$ & $\tau$ & 4 & $\mathrm{Y}$ & $\mathrm{c}$ & 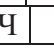 & $\mathrm{Y}$ & $\mathrm{Y}$ & $\mathrm{Y}$ & $\mathrm{Y}$ & $\mathrm{Y}$ & $\mathrm{Y}$ & \\
\hline \multicolumn{27}{|c|}{ Дослідні польові ізоляти } \\
\hline \multirow{2}{*}{\multicolumn{2}{|c|}{$\begin{array}{l}\text { За } \\
\text { EUCASTom }\end{array}$}} & $\mathrm{Y} \geq$ & 18 & 18 & 24 & & 17 & 21 & & 21 & 18 & & 22 & 21 & 2 & 6 & 17 & 2 & 22 & 18 & 22 & 17 & 26 & 20 & \multirow{2}{*}{$\begin{array}{c}\text { */за } \\
\text { чутливістю } \\
\text { до цефок- } \\
\text { сітину } \\
\end{array}$} & \\
\hline & & $\mathrm{P}<$ & 18 & 18 & 24 & & 14 & 21 & & 18 & 16 & & 22 & 21 & 2 & 3 & 14 & 1 & 19 & 18 & 22 & 17 & 26 & 20 & & \\
\hline \multirow[t]{2}{*}{1} & \multirow[t]{2}{*}{$\begin{array}{c}\text { S. aureus } \\
\text { штам } \\
\text { «18» }\end{array}$} & облік & 19 & 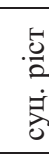 & 18 & & 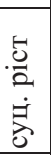 & 22 & & 24 & 14 & & 22 & 21 & 1 & & 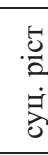 & & 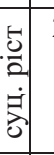 & 20 & 10 & 16 & 14 & 24 & $* / 10$ & \multirow[t]{2}{*}{$\begin{array}{l}\text { резистент. } \\
\text { до } 11 \text { видів } \\
\text { антибіот } \\
\text { / 61,1\% }\end{array}$} \\
\hline & & оцінка & Ч & $\mathrm{P}$ & $\mathrm{P}$ & & $\mathrm{P}$ & 4 & & $\mathrm{Y}$ & $\mathrm{P}$ & & $\mathrm{Y}$ & $\mathrm{Y}$ & 1 & $\mathrm{P}$ & $\mathrm{P}$ & $\mathrm{P}$ & $\bar{P}$ & Ч & $\mathrm{P}$ & $\mathrm{P}$ & $\mathrm{P}$ & 4 & $\mathrm{P}$ & \\
\hline \multirow{2}{*}{2} & \multirow{2}{*}{$\begin{array}{c}\text { S. aureus } \\
\text { штам } \\
\ll 21 / 61 » \\
\end{array}$} & облік & 19 & 20 & 2 & & 25 & 26 & & 20 & 1 & & 29 & 28 & & 26 & 21 & 2 & 24 & 19 & 23 & 25 & 33 & 27 & $* / 26$ & \multirow{2}{*}{$\begin{array}{l}\text { резистент } \\
\text { ності не } \\
\text { виявлено }\end{array}$} \\
\hline & & оцінка & $\mathrm{Y}$ & $\mathrm{Y}$ & $\mathrm{Y}$ & & $\mathrm{Y}$ & 4 & & Ч & $\mathrm{u}$ & & $\mathrm{Y}$ & $\Psi$ & $\mathrm{r}$ & 4 & Ч & $\mathrm{L}$ & 4 & Ч & $\Psi$ & $\mathrm{Y}$ & $\mathrm{Y}$ & $\mathrm{\Psi}$ & $\mathrm{Y}$ & \\
\hline \multirow[t]{2}{*}{3} & \multirow[t]{2}{*}{$\begin{array}{c}\text { S. aureus } \\
\text { штам } \\
\text { «22/62» }\end{array}$} & облік & 25 & 25 & 3 & & 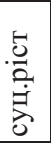 & 34 & & 24 & 15 & & 30 & 31 & 3 & & 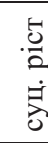 & $\mathrm{X}$ & & 27 & 25 & 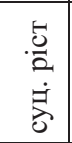 & 14 & 25 & $* / 25$ & \multirow[t]{2}{*}{$\begin{array}{l}\text { резистент } \\
\text { до } 5 \text { видів } \\
\text { антибіот. / } \\
27,5 \%\end{array}$} \\
\hline & & оцінка & $\mathrm{Y}$ & $\mathrm{Y}$ & $\mathrm{L}$ & & $\mathrm{P}$ & $\mathrm{Y}$ & & $\mathrm{Y}$ & $\mathrm{P}$ & & $\mathrm{Y}$ & $\mathrm{\Psi}$ & 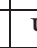 & 4 & $\mathrm{P}$ & $\mathrm{X}$ & $\bar{K}$ & $\mathrm{Y}$ & $\mathrm{Y}$ & $P$ & $\mathrm{P}$ & $\mathrm{Y}$ & $\mathrm{Y}$ & \\
\hline \multirow[t]{2}{*}{4} & \multirow[t]{2}{*}{$\begin{array}{c}\text { S. aureus } \\
\text { штам } \\
\text { «23/53» }\end{array}$} & облік & 19 & 20 & 2 & & 21 & 25 & & $\begin{array}{l}\vec{s} \\
\stackrel{0}{a} \\
\dot{\vec{d}} \\
0\end{array}$ & 17 & & 26 & 24 & 1 & 8 & $\begin{array}{l}\frac{5}{0} \\
\dot{2} \\
\dot{3} \\
\text { गे }\end{array}$ & & 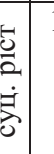 & 19 & 23 & 19 & 31 & 24 & $* / 15$ & \multirow[t]{2}{*}{$\begin{array}{l}\text { резистент } \\
\text { до } 4 \text { видів } \\
\text { антибіот } \\
\text { / 22,2 \% }\end{array}$} \\
\hline & & оцінка & 4 & $\mathrm{Y}$ & $\mathrm{L}$ & & $\mathrm{Y}$ & $\mathrm{Y}$ & & $\mathrm{P}$ & $\mathrm{u}$ & & $\mathrm{Y}$ & $\mathrm{Y}$ & 1 & $P$ & $\mathrm{P}$ & $\mathrm{P}$ & & 4 & $\mathrm{Y}$ & $\mathrm{Y}$ & $\mathrm{Y}$ & $\mathrm{Y}$ & $\mathrm{Y}$ & \\
\hline \multirow[t]{2}{*}{5} & $\begin{array}{c}\text { S. aureus } \\
\text { штам } \\
\ll 27 »\end{array}$ & облік & 22 & 21 & 3 & & 21 & 27 & & 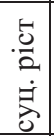 & 19 & & 4 & 26 & 2 & & 21 & 24 & 4 & 24 & 23 & 22 & 12 & 26 & $* / 24$ & $\begin{array}{l}\text { резистент } \\
\text { до } 2 \text { видів } \\
\text { антибіот }\end{array}$ \\
\hline & & оцінка & $\mathrm{Y}$ & $\mathrm{Y}$ & $\mathrm{L}$ & & $\mathrm{Y}$ & $\mathrm{Y}$ & & $\mathrm{P}$ & $\mathrm{Y}$ & & $\mathrm{Y}$ & $\mathrm{Y}$ & 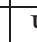 & 4 & $\mathrm{Y}$ & $\mathrm{Y}$ & H & $\mathrm{Y}$ & $\mathrm{\Psi}$ & $\mathrm{Y}$ & $\mathrm{P}$ & $\mathrm{Y}$ & $\mathrm{Y}$ & \\
\hline 6 & \begin{tabular}{|c|} 
S. aureus \\
штам \\
«28»
\end{tabular} & облік & 18 & 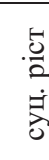 & 1 & & 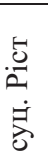 & 25 & & 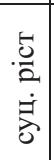 & 15 & & 10 & 17 & 1 & 0 & 5 & 11 & & 17 & 10 & 10 & $\begin{array}{l}1 \\
1\end{array}$ & 12 & $* / 10$ & $\begin{array}{l}\text { резистент } \\
\text { до } 16 \text { видів } \\
\text { антибіот. } \\
\text { / 88,9 \% }\end{array}$ \\
\hline & & оцінка & 4 & $\mathrm{P}$ & $\mathrm{P}$ & & $\mathrm{P}$ & $\mathrm{Y}$ & & $\mathrm{P}$ & $\mathrm{P}$ & & $\mathrm{P}$ & $\mathrm{P}$ & I & $P$ & $\mathrm{P}$ & $\mathrm{P}$ & $P$ & $\mathrm{P}$ & $\mathrm{P}$ & $\mathrm{P}$ & $\mathrm{P}$ & $\mathrm{P}$ & $\mathrm{P}$ & \\
\hline 7 & $\begin{array}{c}\text { S. aureus } \\
\text { штам } \\
\text { «30/60» }\end{array}$ & облік & 19 & 18 & 1 & & . & 24 & & 21 & 11 & & 23 & 13 & & $\begin{array}{l}\vec{y} \\
\dot{0} \\
\dot{2} \\
\dot{\vec{\delta}}\end{array}$ & $\begin{array}{l}\cdot \frac{0}{2} \\
\dot{0} \\
\dot{8}\end{array}$ & & 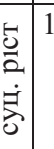 & 19 & 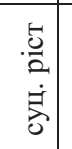 & 19 & 16 & 19 & $\begin{array}{c}* / \text { суц. } \\
\text { ріст }\end{array}$ & $\begin{array}{l}\text { резистент } \\
\text { до } 11 \text { видів } \\
\text { анти біот. / } \\
61,1 \%\end{array}$ \\
\hline & & оцінка & $\mathrm{Y}$ & $\mathrm{\Psi}$ & P & & $\mathrm{P}$ & $\mathrm{Y}$ & & $\mathrm{Y}$ & $\mathrm{P}$ & & Ч & P & 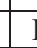 & $P$ & $\mathrm{P}$ & $\mathrm{P}$ & $P$ & Ч & $\mathrm{P}$ & Ч & $\mathrm{P}$ & $\mathrm{P}$ & $\mathrm{P}$ & \\
\hline
\end{tabular}

Примітка: * - резистентність S. aureus до оксициліну визначають по рівню резистентності стафілококів до цефоксітину (за EUCASToм )

За результатами досліджень з вивчення дії дезінфектантів на стафілококи виявилося, що тестова культура S. aureus ATCC 25923 проявляла чутливість до всіх робочих 
концентрацій дослідних дезінфектантів, що підтверджувало достовірність наступних одержаних результатів (табл. 3.).

Характер дії дезінфікуючого засобу № 1 за 30 хв експозиції у концентраціях 0,25; 0,5 і $1,0 \%$ відзначався повною загибеллю польових ізолятів стафілококів, окрім трьох оксацилінрезистентних штамів - S. aureus штам «18», «28» і «30/60». У означених MRSA штамів стафілококів 0,25 \% концентрація робочого розчину дезінфікуючого засобу №1 потужно інгібувала ріст і розмноження бактерій, оскільки після посіву виросли поодинокі колонії збудника, порівняно з суцільним ростом у контролі на твердих поживних середовищах та характерним ростом на ТСБ з його помутнінням та випаданням осаду.

Дезінфікуючі засоби №2 та №3 за експозиції 30 хв бактерицидно діяли на польові ізоляти золотистого стафілокока, окрім $S$. aureus штам «25» (MRSA) у робочій концентрації $0,005 \%$. Не зважаючи на високу бактерицидну активність означених дезінфектантів, концентрація 0,005 \% виявилася не спроможною подолати стійкість збудника, що підтверджувалося ростом на твердих поживних середовищах поодиноких колоній збудника, порівняно з їхнім суцільним ростом у контролі. Ріст збудника у вигляді помутніння ТСБ і випаданням осаду був виявлений у ТСБ, що підтверджувало наявність живих стафілококів після дії 0,005 \% робочих розчинів обох дезінфектантів.

Таблиия 3

\section{Результати досліджень з вивчення бактерицидної дії деяких дезінфікуючих засобів} на польові ізоляти $S$. aureus; $\mathrm{n}_{=} 7$

\begin{tabular}{|c|c|c|c|c|c|c|c|c|c|}
\hline \multirow{2}{*}{ 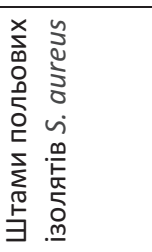 } & \multirow[b]{2}{*}{ 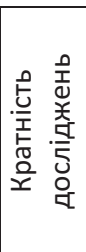 } & \multicolumn{8}{|c|}{$\begin{array}{l}\text { Характер росту тестової культури та польових ізолятів S. aureus на поживних середовищах після дії } \\
\text { дезінфікуючих препаратів у відповідних концентраціях }\end{array}$} \\
\hline & & \multicolumn{3}{|c|}{$\begin{array}{c}\text { Триптон-соєвий агар } \\
\text { (тверде поживне середовище) }\end{array}$} & 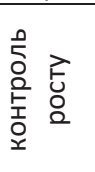 & \multicolumn{3}{|c|}{$\begin{array}{c}\text { Триптон-соєвий бульйон } \\
\text { (рідке поживне } \\
\text { середовище) }\end{array}$} & 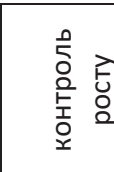 \\
\hline \multicolumn{10}{|c|}{ Дезінфікуючий засіб №1 } \\
\hline \multicolumn{10}{|c|}{ Експозиція 30 хв } \\
\hline \multicolumn{10}{|c|}{ Робочі концентрації, \% } \\
\hline \multicolumn{2}{|l|}{$X$} & 0,25 & 0,5 & 1,0 & $x$ & 0,25 & 0,5 & 1,0 & $x$ \\
\hline \multirow{3}{*}{ 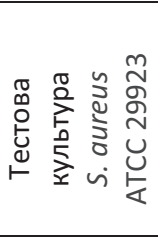 } & 1 & $\begin{array}{c}\text { ріст } \\
\text { відсутній }\end{array}$ & $\begin{array}{c}\text { ріст } \\
\text { відсутній }\end{array}$ & $\begin{array}{c}\text { ріст } \\
\text { відсутній }\end{array}$ & \multirow{3}{*}{ : } & $\begin{array}{c}\text { ріст } \\
\text { відсутній }\end{array}$ & $\begin{array}{c}\text { ріст } \\
\text { відсутній }\end{array}$ & $\begin{array}{c}\text { ріст } \\
\text { відсутній }\end{array}$ & \multirow{3}{*}{ 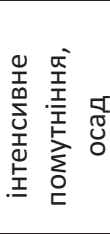 } \\
\hline & 2 & $\begin{array}{c}\text { ріст } \\
\text { відсутній }\end{array}$ & $\begin{array}{c}\text { ріст } \\
\text { відсутній }\end{array}$ & $\begin{array}{c}\text { ріст } \\
\text { відсутній }\end{array}$ & & $\begin{array}{c}\text { ріст } \\
\text { відсутній }\end{array}$ & $\begin{array}{c}\text { ріст } \\
\text { відсутній }\end{array}$ & $\begin{array}{c}\text { ріст } \\
\text { відсутній }\end{array}$ & \\
\hline & 3 & $\begin{array}{c}\text { ріст } \\
\text { відсутній }\end{array}$ & $\begin{array}{c}\text { ріст } \\
\text { відсутній }\end{array}$ & $\begin{array}{c}\text { ріст } \\
\text { відсутній }\end{array}$ & & $\begin{array}{c}\text { ріст } \\
\text { відсутній }\end{array}$ & $\begin{array}{c}\text { ріст } \\
\text { відсутній }\end{array}$ & $\begin{array}{c}\text { ріст } \\
\text { відсутній }\end{array}$ & \\
\hline \multirow{3}{*}{ 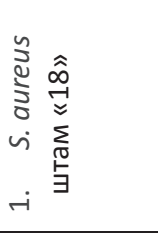 } & 1 & $\begin{array}{c}\text { поодинокі } \\
\text { колонії }\end{array}$ & $\begin{array}{c}\text { ріст } \\
\text { відсутній }\end{array}$ & $\begin{array}{c}\text { ріст } \\
\text { відсутній }\end{array}$ & \multirow{3}{*}{ 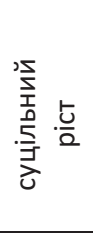 } & $\begin{array}{c}\text { помутніння } \\
\text { середовища, ріст (+) }\end{array}$ & $\begin{array}{c}\text { ріст } \\
\text { відсутній }\end{array}$ & $\begin{array}{c}\text { ріст } \\
\text { відсутній }\end{array}$ & \multirow{3}{*}{ 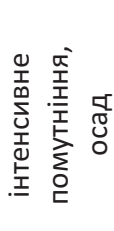 } \\
\hline & 2 & $\begin{array}{c}\text { поодинокі } \\
\text { колонії }\end{array}$ & $\begin{array}{c}\text { ріст } \\
\text { відсутній }\end{array}$ & $\begin{array}{c}\text { ріст } \\
\text { відсутній }\end{array}$ & & $\begin{array}{c}\text { помутніння } \\
\text { середовища, ріст (+) }\end{array}$ & $\begin{array}{c}\text { ріст } \\
\text { відсутній }\end{array}$ & $\begin{array}{c}\text { ріст } \\
\text { відсутній }\end{array}$ & \\
\hline & 3 & $\begin{array}{c}\text { поодинокі } \\
\text { колонії }\end{array}$ & $\begin{array}{c}\text { ріст } \\
\text { відсутній }\end{array}$ & $\begin{array}{c}\text { ріст } \\
\text { відсутній }\end{array}$ & & $\begin{array}{c}\text { помутніння } \\
\text { середовища, ріст (+) }\end{array}$ & $\begin{array}{c}\text { ріст } \\
\text { відсутній }\end{array}$ & $\begin{array}{c}\text { ріст } \\
\text { відсутній }\end{array}$ & \\
\hline \multirow{3}{*}{ 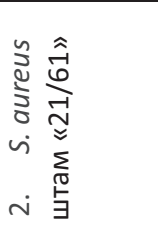 } & 1 & $\begin{array}{c}\text { ріст } \\
\text { відсутній }\end{array}$ & $\begin{array}{c}\text { ріст } \\
\text { відсутній }\end{array}$ & $\begin{array}{c}\text { ріст } \\
\text { відсутній }\end{array}$ & \multirow{3}{*}{ 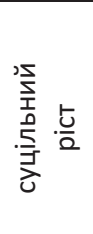 } & $\begin{array}{c}\text { ріст } \\
\text { відсутній }\end{array}$ & $\begin{array}{c}\text { ріст } \\
\text { відсутній }\end{array}$ & $\begin{array}{c}\text { ріст } \\
\text { відсутній }\end{array}$ & \multirow{3}{*}{ 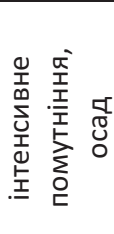 } \\
\hline & 2 & $\begin{array}{c}\text { ріст } \\
\text { відсутній }\end{array}$ & $\begin{array}{c}\text { ріст } \\
\text { відсутній }\end{array}$ & $\begin{array}{c}\text { ріст } \\
\text { відсутній }\end{array}$ & & $\begin{array}{c}\text { ріст } \\
\text { відсутній }\end{array}$ & $\begin{array}{c}\text { ріст } \\
\text { відсутній }\end{array}$ & $\begin{array}{c}\text { ріст } \\
\text { відсутній }\end{array}$ & \\
\hline & 3 & $\begin{array}{c}\text { ріст } \\
\text { відсутній }\end{array}$ & $\begin{array}{c}\text { ріст } \\
\text { відсутній }\end{array}$ & $\begin{array}{c}\text { ріст } \\
\text { відсутній }\end{array}$ & & $\begin{array}{c}\text { ріст } \\
\text { відсутній }\end{array}$ & $\begin{array}{c}\text { ріст } \\
\text { відсутній }\end{array}$ & $\begin{array}{c}\text { ріст } \\
\text { відсутній }\end{array}$ & \\
\hline \multirow{3}{*}{ 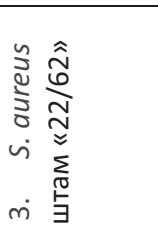 } & 1 & $\begin{array}{c}\text { ріст } \\
\text { відсутній }\end{array}$ & $\begin{array}{c}\text { ріст } \\
\text { відсутній }\end{array}$ & $\begin{array}{c}\text { ріст } \\
\text { відсутній }\end{array}$ & \multirow{3}{*}{ 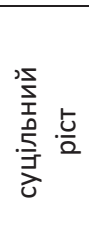 } & $\begin{array}{c}\text { ріст } \\
\text { відсутній }\end{array}$ & $\begin{array}{c}\text { ріст } \\
\text { відсутній }\end{array}$ & $\begin{array}{c}\text { ріст } \\
\text { відсутній }\end{array}$ & \multirow{3}{*}{ 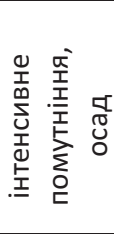 } \\
\hline & 2 & $\begin{array}{c}\text { ріст } \\
\text { відсутній }\end{array}$ & $\begin{array}{c}\text { ріст } \\
\text { відсутній }\end{array}$ & $\begin{array}{c}\text { ріст } \\
\text { відсутній }\end{array}$ & & $\begin{array}{c}\text { ріст } \\
\text { відсутній }\end{array}$ & $\begin{array}{c}\text { ріст } \\
\text { відсутній }\end{array}$ & $\begin{array}{c}\text { ріст } \\
\text { відсутній }\end{array}$ & \\
\hline & 3 & $\begin{array}{c}\text { ріст } \\
\text { відсутній }\end{array}$ & $\begin{array}{c}\text { ріст } \\
\text { відсутній }\end{array}$ & $\begin{array}{c}\text { ріст } \\
\text { відсутній }\end{array}$ & & $\begin{array}{c}\text { ріст } \\
\text { відсутній }\end{array}$ & $\begin{array}{c}\text { ріст } \\
\text { відсутній }\end{array}$ & $\begin{array}{c}\text { ріст } \\
\text { відсутній }\end{array}$ & \\
\hline
\end{tabular}




\begin{tabular}{|c|c|c|c|c|c|c|c|c|c|}
\hline \multirow{3}{*}{ 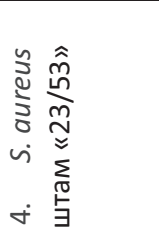 } & 1 & $\begin{array}{c}\text { ріст } \\
\text { відсутній }\end{array}$ & $\begin{array}{c}\text { ріст } \\
\text { відсутній }\end{array}$ & $\begin{array}{c}\text { ріст } \\
\text { відсутній }\end{array}$ & \multirow{3}{*}{ 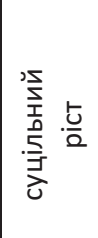 } & $\begin{array}{c}\text { ріст } \\
\text { відсутній }\end{array}$ & $\begin{array}{c}\text { ріст } \\
\text { відсутній }\end{array}$ & $\begin{array}{c}\text { ріст } \\
\text { відсутній }\end{array}$ & \multirow{3}{*}{ 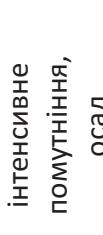 } \\
\hline & 2 & $\begin{array}{c}\text { ріст } \\
\text { відсутній }\end{array}$ & $\begin{array}{c}\text { ріст } \\
\text { відсутній }\end{array}$ & $\begin{array}{c}\text { ріст } \\
\text { відсутній }\end{array}$ & & $\begin{array}{c}\text { ріст } \\
\text { відсутній }\end{array}$ & $\begin{array}{c}\text { ріст } \\
\text { відсутній }\end{array}$ & $\begin{array}{c}\text { ріст } \\
\text { відсутній }\end{array}$ & \\
\hline & 3 & $\begin{array}{c}\text { ріст } \\
\text { відсутній }\end{array}$ & $\begin{array}{c}\text { ріст } \\
\text { відсутній }\end{array}$ & $\begin{array}{c}\text { ріст } \\
\text { відсутній }\end{array}$ & & $\begin{array}{c}\text { ріст } \\
\text { відсутній }\end{array}$ & $\begin{array}{c}\text { ріст } \\
\text { відсутній }\end{array}$ & $\begin{array}{c}\text { ріст } \\
\text { відсутній }\end{array}$ & \\
\hline \multirow{3}{*}{ 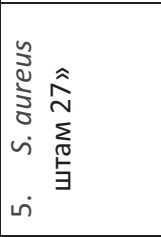 } & 1 & $\begin{array}{c}\text { ріст } \\
\text { відсутній }\end{array}$ & $\begin{array}{c}\text { ріст } \\
\text { відсутній }\end{array}$ & $\begin{array}{c}\text { ріст } \\
\text { відсутній }\end{array}$ & \multirow{3}{*}{ } & $\begin{array}{c}\text { ріст } \\
\text { відсутній }\end{array}$ & $\begin{array}{c}\text { ріст } \\
\text { відсутній }\end{array}$ & $\begin{array}{c}\text { ріст } \\
\text { відсутній }\end{array}$ & \multirow{3}{*}{ 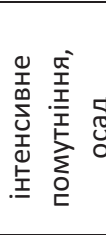 } \\
\hline & 2 & $\begin{array}{c}\text { ріст } \\
\text { відсутній }\end{array}$ & $\begin{array}{c}\text { ріст } \\
\text { відсутній }\end{array}$ & $\begin{array}{c}\text { ріст } \\
\text { відсутній }\end{array}$ & & $\begin{array}{c}\text { ріст } \\
\text { відсутній }\end{array}$ & $\begin{array}{c}\text { ріст } \\
\text { відсутній }\end{array}$ & $\begin{array}{c}\text { ріст } \\
\text { відсутній }\end{array}$ & \\
\hline & 3 & $\begin{array}{c}\text { ріст } \\
\text { відсутній } \\
\end{array}$ & $\begin{array}{c}\text { ріст } \\
\text { відсутній }\end{array}$ & $\begin{array}{c}\text { ріст } \\
\text { відсутній }\end{array}$ & & $\begin{array}{c}\text { ріст } \\
\text { відсутній } \\
\end{array}$ & $\begin{array}{c}\text { ріст } \\
\text { відсутній }\end{array}$ & $\begin{array}{c}\text { ріст } \\
\text { відсутній }\end{array}$ & \\
\hline \multirow{3}{*}{ 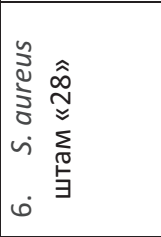 } & 1 & $\begin{array}{c}\text { поодинокі } \\
\text { колонії }\end{array}$ & $\begin{array}{c}\text { ріст } \\
\text { відсутній }\end{array}$ & $\begin{array}{c}\text { ріст } \\
\text { відсутній }\end{array}$ & \multirow{3}{*}{ 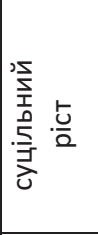 } & $\begin{array}{c}\text { помутніння } \\
\text { середовища, ріст (+) }\end{array}$ & $\begin{array}{c}\text { ріст } \\
\text { відсутній }\end{array}$ & $\begin{array}{c}\text { ріст } \\
\text { відсутній }\end{array}$ & \multirow{3}{*}{ 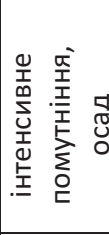 } \\
\hline & 2 & $\begin{array}{c}\text { поодинокі } \\
\text { колонії }\end{array}$ & $\begin{array}{c}\text { ріст } \\
\text { відсутній }\end{array}$ & $\begin{array}{c}\text { ріст } \\
\text { відсутній }\end{array}$ & & $\begin{array}{c}\text { помутніння } \\
\text { середовища, ріст (+) }\end{array}$ & $\begin{array}{c}\text { ріст } \\
\text { відсутній }\end{array}$ & $\begin{array}{c}\text { ріст } \\
\text { відсутній }\end{array}$ & \\
\hline & 3 & $\begin{array}{c}\text { поодинокі } \\
\text { колонії }\end{array}$ & $\begin{array}{c}\text { ріст } \\
\text { відсутній }\end{array}$ & $\begin{array}{c}\text { ріст } \\
\text { відсутній }\end{array}$ & & $\begin{array}{c}\text { помутніння } \\
\text { середовища, ріст (+) }\end{array}$ & $\begin{array}{c}\text { ріст } \\
\text { відсутній }\end{array}$ & $\begin{array}{c}\text { ріст } \\
\text { відсутній }\end{array}$ & \\
\hline \multirow{3}{*}{ 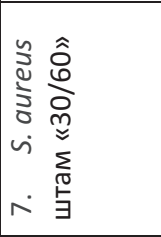 } & 1 & $\begin{array}{c}\text { поодинокі } \\
\text { колонії }\end{array}$ & $\begin{array}{c}\text { ріст } \\
\text { відсутній }\end{array}$ & $\begin{array}{c}\text { ріст } \\
\text { відсутній }\end{array}$ & \multirow{3}{*}{ 疍 } & $\begin{array}{c}\text { помутніння } \\
\text { середовища, ріст (+) }\end{array}$ & $\begin{array}{c}\text { ріст } \\
\text { відсутній }\end{array}$ & $\begin{array}{c}\text { ріст } \\
\text { відсутній }\end{array}$ & \multirow{3}{*}{ 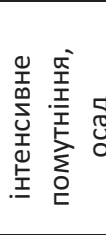 } \\
\hline & 2 & $\begin{array}{c}\text { поодинокі } \\
\text { колонії }\end{array}$ & $\begin{array}{c}\text { ріст } \\
\text { відсутній }\end{array}$ & $\begin{array}{c}\text { ріст } \\
\text { відсутній }\end{array}$ & & $\begin{array}{c}\text { помутніння } \\
\text { середовища, ріст (+) }\end{array}$ & $\begin{array}{c}\text { ріст } \\
\text { відсутній }\end{array}$ & $\begin{array}{c}\text { ріст } \\
\text { відсутній }\end{array}$ & \\
\hline & 3 & $\begin{array}{c}\text { поодинокі } \\
\text { колонії }\end{array}$ & $\begin{array}{c}\text { ріст } \\
\text { відсутній }\end{array}$ & $\begin{array}{c}\text { ріст } \\
\text { відсутній }\end{array}$ & & $\begin{array}{c}\text { помутніння } \\
\text { середовища, ріст (+) }\end{array}$ & $\begin{array}{c}\text { ріст } \\
\text { відсутній } \\
\end{array}$ & $\begin{array}{c}\text { ріст } \\
\text { відсутній }\end{array}$ & \\
\hline \multicolumn{10}{|c|}{ Дезінфікуючий засіб №2 } \\
\hline \multicolumn{10}{|c|}{ Експозиція 30 хв } \\
\hline \multicolumn{10}{|c|}{ Робочі концентрації } \\
\hline \multicolumn{2}{|l|}{$\mathrm{X}$} & 0,05 & 0,25 & 0,5 & $\mathrm{X}$ & 0,05 & 0,25 & 0,5 & $\mathrm{X}$ \\
\hline \multirow{3}{*}{ 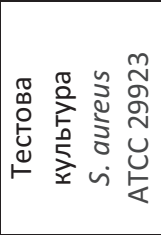 } & 1 & $\begin{array}{c}\text { ріст } \\
\text { відсутній }\end{array}$ & $\begin{array}{c}\text { ріст } \\
\text { відсутній }\end{array}$ & $\begin{array}{c}\text { ріст } \\
\text { відсутній }\end{array}$ & \multirow{3}{*}{ 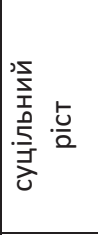 } & $\begin{array}{c}\text { ріст } \\
\text { відсутній } \\
\end{array}$ & $\begin{array}{c}\text { ріст } \\
\text { відсутній }\end{array}$ & $\begin{array}{c}\text { ріст } \\
\text { відсутній }\end{array}$ & \multirow{3}{*}{ 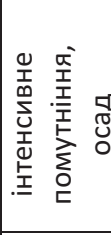 } \\
\hline & 2 & $\begin{array}{c}\text { ріст } \\
\text { відсутній } \\
\end{array}$ & $\begin{array}{c}\text { ріст } \\
\text { відсутній } \\
\end{array}$ & $\begin{array}{c}\text { ріст } \\
\text { відсутній } \\
\end{array}$ & & $\begin{array}{c}\text { ріст } \\
\text { відсутній } \\
\end{array}$ & $\begin{array}{c}\text { ріст } \\
\text { відсутній } \\
\end{array}$ & $\begin{array}{c}\text { ріст } \\
\text { відсутній } \\
\end{array}$ & \\
\hline & 3 & $\begin{array}{c}\text { ріст } \\
\text { відсутній }\end{array}$ & $\begin{array}{c}\text { ріст } \\
\text { відсутній } \\
\end{array}$ & $\begin{array}{c}\text { ріст } \\
\text { відсутній } \\
\end{array}$ & & $\begin{array}{c}\text { ріст } \\
\text { відсутній }\end{array}$ & $\begin{array}{c}\text { ріст } \\
\text { відсутній }\end{array}$ & $\begin{array}{c}\text { ріст } \\
\text { відсутній }\end{array}$ & \\
\hline \multirow{3}{*}{ 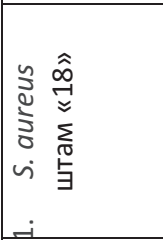 } & 1 & $\begin{array}{c}\text { ріст } \\
\text { відсутній }\end{array}$ & $\begin{array}{c}\text { ріст } \\
\text { відсутній }\end{array}$ & $\begin{array}{c}\text { ріст } \\
\text { відсутній }\end{array}$ & \multirow{3}{*}{ 永 } & $\begin{array}{c}\text { ріст } \\
\text { відсутній }\end{array}$ & $\begin{array}{c}\text { ріст } \\
\text { відсутній }\end{array}$ & $\begin{array}{c}\text { ріст } \\
\text { відсутній }\end{array}$ & \multirow{3}{*}{ 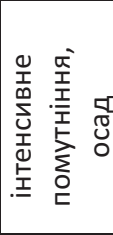 } \\
\hline & 2 & $\begin{array}{c}\text { ріст } \\
\text { відсутній }\end{array}$ & $\begin{array}{c}\text { ріст } \\
\text { відсутній }\end{array}$ & $\begin{array}{c}\text { ріст } \\
\text { відсутній }\end{array}$ & & $\begin{array}{c}\text { ріст } \\
\text { відсутній }\end{array}$ & $\begin{array}{c}\text { ріст } \\
\text { відсутній }\end{array}$ & $\begin{array}{c}\text { ріст } \\
\text { відсутній }\end{array}$ & \\
\hline & 3 & $\begin{array}{c}\text { ріст } \\
\text { відсутній }\end{array}$ & $\begin{array}{c}\text { ріст } \\
\text { відсутній }\end{array}$ & $\begin{array}{c}\text { ріст } \\
\text { відсутній }\end{array}$ & & $\begin{array}{c}\text { ріст } \\
\text { відсутній } \\
\end{array}$ & $\begin{array}{c}\text { ріст } \\
\text { відсутній }\end{array}$ & $\begin{array}{c}\text { ріст } \\
\text { відсутній }\end{array}$ & \\
\hline \multirow{3}{*}{ 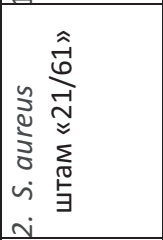 } & 1 & $\begin{array}{c}\text { ріст } \\
\text { відсутній } \\
\end{array}$ & $\begin{array}{c}\text { ріст } \\
\text { відсутній } \\
\end{array}$ & $\begin{array}{c}\text { ріст } \\
\text { відсутній } \\
\end{array}$ & \multirow{3}{*}{ : } & $\begin{array}{c}\text { ріст } \\
\text { відсутній } \\
\end{array}$ & $\begin{array}{c}\text { ріст } \\
\text { відсутній } \\
\end{array}$ & $\begin{array}{c}\text { ріст } \\
\text { відсутній }\end{array}$ & \multirow{3}{*}{ 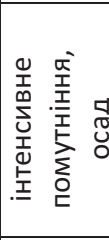 } \\
\hline & 2 & $\begin{array}{c}\text { ріст } \\
\text { відсутній } \\
\end{array}$ & $\begin{array}{c}\text { ріст } \\
\text { відсутній } \\
\end{array}$ & $\begin{array}{c}\text { ріст } \\
\text { відсутній } \\
\end{array}$ & & $\begin{array}{c}\text { ріст } \\
\text { відсутній } \\
\end{array}$ & $\begin{array}{c}\text { ріст } \\
\text { відсутній } \\
\end{array}$ & $\begin{array}{c}\text { ріст } \\
\text { відсутній } \\
\end{array}$ & \\
\hline & 3 & $\begin{array}{c}\text { ріст } \\
\text { відсутній }\end{array}$ & $\begin{array}{c}\text { ріст } \\
\text { відсутній }\end{array}$ & $\begin{array}{c}\text { ріст } \\
\text { відсутній }\end{array}$ & & $\begin{array}{c}\text { ріст } \\
\text { відсутній }\end{array}$ & $\begin{array}{c}\text { ріст } \\
\text { відсутній }\end{array}$ & $\begin{array}{c}\text { ріст } \\
\text { відсутній }\end{array}$ & \\
\hline \multirow{3}{*}{ 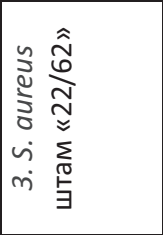 } & 1 & $\begin{array}{c}\text { ріст } \\
\text { відсутній }\end{array}$ & $\begin{array}{c}\text { ріст } \\
\text { відсутній }\end{array}$ & $\begin{array}{c}\text { ріст } \\
\text { відсутній }\end{array}$ & \multirow{3}{*}{ : } & $\begin{array}{c}\text { ріст } \\
\text { відсутній }\end{array}$ & $\begin{array}{c}\text { ріст } \\
\text { відсутній }\end{array}$ & $\begin{array}{c}\text { ріст } \\
\text { відсутній }\end{array}$ & \multirow{3}{*}{ 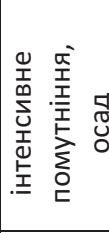 } \\
\hline & 2 & $\begin{array}{c}\text { ріст } \\
\text { відсутній }\end{array}$ & $\begin{array}{c}\text { ріст } \\
\text { відсутній }\end{array}$ & $\begin{array}{c}\text { ріст } \\
\text { відсутній }\end{array}$ & & $\begin{array}{c}\text { ріст } \\
\text { відсутній }\end{array}$ & $\begin{array}{c}\text { ріст } \\
\text { відсутній }\end{array}$ & $\begin{array}{c}\text { ріст } \\
\text { відсутній }\end{array}$ & \\
\hline & 3 & $\begin{array}{c}\text { ріст } \\
\text { відсутній }\end{array}$ & $\begin{array}{c}\text { ріст } \\
\text { відсутній } \\
\end{array}$ & $\begin{array}{c}\text { ріст } \\
\text { відсутній } \\
\end{array}$ & & $\begin{array}{c}\text { ріст } \\
\text { відсутній }\end{array}$ & $\begin{array}{c}\text { ріст } \\
\text { відсутній }\end{array}$ & $\begin{array}{c}\text { ріст } \\
\text { відсутній }\end{array}$ & \\
\hline 气 & 1. & $\begin{array}{c}\text { ріст } \\
\text { відсутній }\end{array}$ & $\begin{array}{c}\text { ріст } \\
\text { відсутній }\end{array}$ & $\begin{array}{c}\text { ріст } \\
\text { відсутній }\end{array}$ & & $\begin{array}{c}\text { ріст } \\
\text { відсутній }\end{array}$ & $\begin{array}{c}\text { ріст } \\
\text { відсутній }\end{array}$ & $\begin{array}{c}\text { ріст } \\
\text { відсутній }\end{array}$ & $\stackrel{0}{\dddot{0}}$ \\
\hline 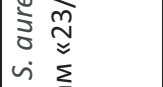 & 2. & $\begin{array}{c}\text { ріст } \\
\text { відсутній } \\
\end{array}$ & $\begin{array}{c}\text { ріст } \\
\text { відсутній } \\
\end{array}$ & $\begin{array}{c}\text { ріст } \\
\text { відсутній } \\
\end{array}$ & 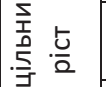 & $\begin{array}{c}\text { ріст } \\
\text { відсутній } \\
\end{array}$ & $\begin{array}{c}\text { ріст } \\
\text { відсутній } \\
\end{array}$ & $\begin{array}{c}\text { ріст } \\
\text { відсутній }\end{array}$ & 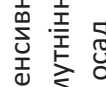 \\
\hline$\nabla \stackrel{\bar{\Xi}}{\exists}$ & 3. & $\begin{array}{c}\text { ріст } \\
\text { відсутній }\end{array}$ & $\begin{array}{c}\text { ріст } \\
\text { відсутній }\end{array}$ & $\begin{array}{c}\text { ріст } \\
\text { відсутній }\end{array}$ & 己 & $\begin{array}{c}\text { ріст } \\
\text { відсутній }\end{array}$ & $\begin{array}{c}\text { ріст } \\
\text { відсутній }\end{array}$ & $\begin{array}{c}\text { ріст } \\
\text { відсутній }\end{array}$ & 농 \\
\hline 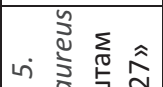 & 1 & $\begin{array}{c}\text { ріст } \\
\text { відсутній }\end{array}$ & $\begin{array}{c}\text { ріст } \\
\text { відсутній }\end{array}$ & $\begin{array}{c}\text { ріст } \\
\text { відсутній }\end{array}$ & ת & $\begin{array}{c}\text { ріст } \\
\text { відсутній }\end{array}$ & $\begin{array}{c}\text { ріст } \\
\text { відсутній }\end{array}$ & $\begin{array}{c}\text { ріст } \\
\text { відсутній }\end{array}$ & 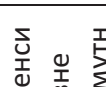 \\
\hline vi & 2 & ріст & ріст & pict & ปे & ріст & ріст & ріст & 点 $\underbrace{\infty}$ \\
\hline
\end{tabular}




\begin{tabular}{|c|c|c|c|c|c|c|c|c|c|}
\hline & & відсутній & відсутній & відсутній & & відсутній & відсутній & відсутній & \\
\hline & 3 & $\begin{array}{c}\text { ріст } \\
\text { відсутній }\end{array}$ & $\begin{array}{c}\text { ріст } \\
\text { відсутній }\end{array}$ & $\begin{array}{c}\text { ріст } \\
\text { відсутній }\end{array}$ & & $\begin{array}{c}\text { ріст } \\
\text { відсутній }\end{array}$ & $\begin{array}{c}\text { ріст } \\
\text { відсутній }\end{array}$ & $\begin{array}{c}\text { ріст } \\
\text { відсутній }\end{array}$ & \\
\hline \multirow{3}{*}{ 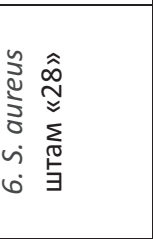 } & 1 & $\begin{array}{c}\text { поодинокі } \\
\text { колонії }\end{array}$ & $\begin{array}{c}\text { ріст } \\
\text { відсутній } \\
\end{array}$ & $\begin{array}{c}\text { ріст } \\
\text { відсутній } \\
\end{array}$ & \multirow{3}{*}{ : } & $\begin{array}{c}\text { помутніння } \\
\text { середовища, ріст (+) }\end{array}$ & $\begin{array}{c}\text { ріст } \\
\text { відсутній } \\
\end{array}$ & $\begin{array}{c}\text { ріст } \\
\text { відсутній } \\
\end{array}$ & \multirow{3}{*}{ 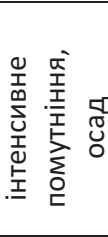 } \\
\hline & 2 & $\begin{array}{c}\text { поодинокі } \\
\text { колонії }\end{array}$ & $\begin{array}{c}\text { ріст } \\
\text { відсутній }\end{array}$ & $\begin{array}{c}\text { ріст } \\
\text { відсутній }\end{array}$ & & $\begin{array}{c}\text { помутніння } \\
\text { середовища, ріст (+) }\end{array}$ & $\begin{array}{c}\text { ріст } \\
\text { відсутній }\end{array}$ & $\begin{array}{c}\text { ріст } \\
\text { відсутній }\end{array}$ & \\
\hline & 3 & $\begin{array}{c}\text { поодинокі } \\
\text { колонії }\end{array}$ & $\begin{array}{c}\text { ріст } \\
\text { відсутній } \\
\end{array}$ & $\begin{array}{c}\text { ріст } \\
\text { відсутній } \\
\end{array}$ & & $\begin{array}{c}\text { помутніння } \\
\text { середовища, ріст (+) }\end{array}$ & $\begin{array}{c}\text { ріст } \\
\text { відсутній } \\
\end{array}$ & $\begin{array}{c}\text { ріст } \\
\text { відсутній } \\
\end{array}$ & \\
\hline \multirow{3}{*}{ 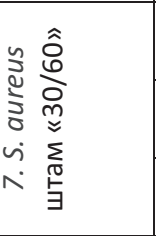 } & 1 & $\begin{array}{c}\text { ріст } \\
\text { відсутній }\end{array}$ & $\begin{array}{c}\text { ріст } \\
\text { відсутній }\end{array}$ & $\begin{array}{c}\text { ріст } \\
\text { відсутній } \\
\end{array}$ & \multirow{3}{*}{ : } & $\begin{array}{c}\text { ріст } \\
\text { відсутній }\end{array}$ & $\begin{array}{c}\text { ріст } \\
\text { відсутній }\end{array}$ & $\begin{array}{c}\text { ріст } \\
\text { відсутній } \\
\end{array}$ & \multirow{3}{*}{ 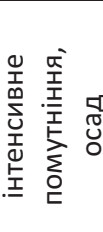 } \\
\hline & 2 & $\begin{array}{c}\text { ріст } \\
\text { відсутній }\end{array}$ & $\begin{array}{c}\text { ріст } \\
\text { відсутній }\end{array}$ & $\begin{array}{c}\text { ріст } \\
\text { відсутній }\end{array}$ & & $\begin{array}{c}\text { ріст } \\
\text { відсутній }\end{array}$ & $\begin{array}{c}\text { ріст } \\
\text { відсутній }\end{array}$ & $\begin{array}{c}\text { ріст } \\
\text { відсутній }\end{array}$ & \\
\hline & 3 & $\begin{array}{c}\text { ріст } \\
\text { відсутній }\end{array}$ & $\begin{array}{c}\text { ріст } \\
\text { відсутній }\end{array}$ & $\begin{array}{c}\text { ріст } \\
\text { відсутній }\end{array}$ & & $\begin{array}{c}\text { ріст } \\
\text { відсутній }\end{array}$ & $\begin{array}{c}\text { ріст } \\
\text { відсутній }\end{array}$ & $\begin{array}{c}\text { ріст } \\
\text { відсутній }\end{array}$ & \\
\hline \multicolumn{10}{|c|}{ Дезінфікуючий засіб №3 } \\
\hline \multicolumn{10}{|c|}{ Експозиція 30 хв } \\
\hline \multicolumn{10}{|c|}{ Робочі концентрації } \\
\hline \multicolumn{2}{|l|}{$\mathrm{X}$} & 0,05 & 0,25 & 0,5 & $x$ & 0,05 & 0,25 & 0,5 & $x$ \\
\hline \multirow{3}{*}{ 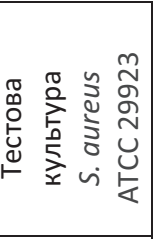 } & 1 & $\begin{array}{c}\text { ріст } \\
\text { відсутній }\end{array}$ & $\begin{array}{c}\text { ріст } \\
\text { відсутній }\end{array}$ & $\begin{array}{c}\text { ріст } \\
\text { відсутній }\end{array}$ & \multirow{3}{*}{ : } & $\begin{array}{c}\text { ріст } \\
\text { відсутній }\end{array}$ & $\begin{array}{c}\text { ріст } \\
\text { відсутній }\end{array}$ & $\begin{array}{c}\text { ріст } \\
\text { відсутній }\end{array}$ & \multirow{3}{*}{ 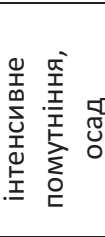 } \\
\hline & 2 & $\begin{array}{c}\text { ріст } \\
\text { відсутній } \\
\end{array}$ & $\begin{array}{c}\text { ріст } \\
\text { відсутній }\end{array}$ & $\begin{array}{c}\text { ріст } \\
\text { відсутній } \\
\end{array}$ & & $\begin{array}{c}\text { ріст } \\
\text { відсутній }\end{array}$ & $\begin{array}{c}\text { ріст } \\
\text { відсутній }\end{array}$ & $\begin{array}{c}\text { ріст } \\
\text { відсутній }\end{array}$ & \\
\hline & 3 & $\begin{array}{c}\text { ріст } \\
\text { відсутній }\end{array}$ & $\begin{array}{c}\text { ріст } \\
\text { відсутній }\end{array}$ & $\begin{array}{c}\text { ріст } \\
\text { відсутній }\end{array}$ & & $\begin{array}{c}\text { ріст } \\
\text { відсутній }\end{array}$ & $\begin{array}{c}\text { ріст } \\
\text { відсутній }\end{array}$ & $\begin{array}{c}\text { ріст } \\
\text { відсутній }\end{array}$ & \\
\hline \multirow{3}{*}{ 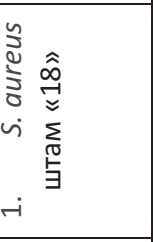 } & 1 & $\begin{array}{c}\text { ріст } \\
\text { відсутній }\end{array}$ & $\begin{array}{c}\text { ріст } \\
\text { відсутній }\end{array}$ & $\begin{array}{c}\text { ріст } \\
\text { відсутній }\end{array}$ & \multirow{3}{*}{ : } & $\begin{array}{c}\text { ріст } \\
\text { відсутній }\end{array}$ & $\begin{array}{c}\text { ріст } \\
\text { відсутній }\end{array}$ & $\begin{array}{c}\text { ріст } \\
\text { відсутній }\end{array}$ & \multirow{3}{*}{ 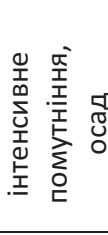 } \\
\hline & 2 & $\begin{array}{c}\text { ріст } \\
\text { відсутній }\end{array}$ & $\begin{array}{c}\text { ріст } \\
\text { відсутній }\end{array}$ & $\begin{array}{c}\text { ріст } \\
\text { відсутній }\end{array}$ & & $\begin{array}{c}\text { ріст } \\
\text { відсутній }\end{array}$ & $\begin{array}{c}\text { ріст } \\
\text { відсутній }\end{array}$ & $\begin{array}{c}\text { ріст } \\
\text { відсутній }\end{array}$ & \\
\hline & 3 & $\begin{array}{c}\text { ріст } \\
\text { відсутній }\end{array}$ & $\begin{array}{c}\text { ріст } \\
\text { відсутній }\end{array}$ & $\begin{array}{c}\text { ріст } \\
\text { відсутній }\end{array}$ & & $\begin{array}{c}\text { ріст } \\
\text { відсутній }\end{array}$ & $\begin{array}{c}\text { ріст } \\
\text { відсутній }\end{array}$ & $\begin{array}{c}\text { ріст } \\
\text { відсутній }\end{array}$ & \\
\hline \multirow{3}{*}{ 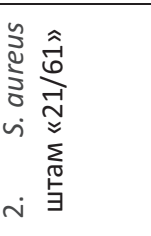 } & 1 & $\begin{array}{c}\text { ріст } \\
\text { відсутній }\end{array}$ & $\begin{array}{c}\text { ріст } \\
\text { відсутній }\end{array}$ & $\begin{array}{c}\text { ріст } \\
\text { відсутній }\end{array}$ & \multirow{3}{*}{ : } & $\begin{array}{c}\text { ріст } \\
\text { відсутній }\end{array}$ & $\begin{array}{c}\text { ріст } \\
\text { відсутній }\end{array}$ & $\begin{array}{c}\text { ріст } \\
\text { відсутній }\end{array}$ & \multirow{3}{*}{ 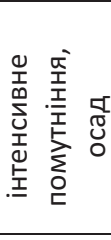 } \\
\hline & 2 & $\begin{array}{c}\text { ріст } \\
\text { відсутній }\end{array}$ & $\begin{array}{c}\text { ріст } \\
\text { відсутній } \\
\end{array}$ & $\begin{array}{c}\text { ріст } \\
\text { відсутній } \\
\end{array}$ & & $\begin{array}{c}\text { ріст } \\
\text { відсутній } \\
\end{array}$ & $\begin{array}{c}\text { ріст } \\
\text { відсутній } \\
\end{array}$ & $\begin{array}{c}\text { ріст } \\
\text { відсутній } \\
\end{array}$ & \\
\hline & 3 & $\begin{array}{c}\text { ріст } \\
\text { відсутній } \\
\end{array}$ & $\begin{array}{c}\text { ріст } \\
\text { відсутній } \\
\end{array}$ & $\begin{array}{c}\text { ріст } \\
\text { відсутній } \\
\end{array}$ & & $\begin{array}{c}\text { ріст } \\
\text { відсутній } \\
\end{array}$ & $\begin{array}{c}\text { ріст } \\
\text { відсутній } \\
\end{array}$ & $\begin{array}{c}\text { ріст } \\
\text { відсутній } \\
\end{array}$ & \\
\hline \multirow{3}{*}{ 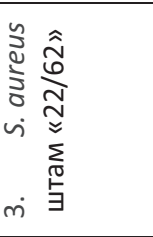 } & 1 & $\begin{array}{c}\text { ріст } \\
\text { відсутній }\end{array}$ & $\begin{array}{c}\text { ріст } \\
\text { відсутній }\end{array}$ & $\begin{array}{c}\text { ріст } \\
\text { відсутній }\end{array}$ & \multirow{3}{*}{. } & $\begin{array}{c}\text { ріст } \\
\text { відсутній }\end{array}$ & $\begin{array}{c}\text { ріст } \\
\text { відсутній }\end{array}$ & $\begin{array}{c}\text { ріст } \\
\text { відсутній }\end{array}$ & \multirow{3}{*}{ 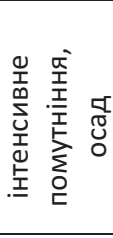 } \\
\hline & 2 & $\begin{array}{c}\text { ріст } \\
\text { відсутній }\end{array}$ & $\begin{array}{c}\text { ріст } \\
\text { відсутній } \\
\end{array}$ & $\begin{array}{c}\text { ріст } \\
\text { відсутній }\end{array}$ & & $\begin{array}{c}\text { ріст } \\
\text { відсутній }\end{array}$ & $\begin{array}{c}\text { ріст } \\
\text { відсутній } \\
\end{array}$ & $\begin{array}{c}\text { ріст } \\
\text { відсутній }\end{array}$ & \\
\hline & 3 & $\begin{array}{c}\text { ріст } \\
\text { відсутній } \\
\end{array}$ & $\begin{array}{c}\text { ріст } \\
\text { відсутній } \\
\end{array}$ & $\begin{array}{c}\text { ріст } \\
\text { відсутній } \\
\end{array}$ & & $\begin{array}{c}\text { ріст } \\
\text { відсутній } \\
\end{array}$ & $\begin{array}{c}\text { ріст } \\
\text { відсутній } \\
\end{array}$ & $\begin{array}{c}\text { ріст } \\
\text { відсутній } \\
\end{array}$ & \\
\hline \multirow{3}{*}{ 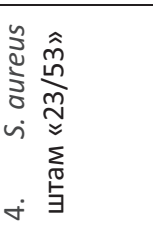 } & 1 & $\begin{array}{c}\text { ріст } \\
\text { відсутній } \\
\end{array}$ & $\begin{array}{c}\text { ріст } \\
\text { відсутній } \\
\end{array}$ & $\begin{array}{c}\text { ріст } \\
\text { відсутній } \\
\end{array}$ & \multirow{3}{*}{ : } & $\begin{array}{c}\text { ріст } \\
\text { відсутній } \\
\end{array}$ & $\begin{array}{c}\text { ріст } \\
\text { відсутній } \\
\end{array}$ & $\begin{array}{c}\text { ріст } \\
\text { відсутній } \\
\end{array}$ & \multirow{3}{*}{ 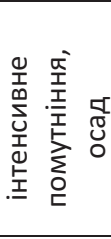 } \\
\hline & 2 & $\begin{array}{c}\text { ріст } \\
\text { відсутній }\end{array}$ & $\begin{array}{c}\text { ріст } \\
\text { відсутній }\end{array}$ & $\begin{array}{c}\text { ріст } \\
\text { відсутній }\end{array}$ & & $\begin{array}{c}\text { ріст } \\
\text { відсутній }\end{array}$ & $\begin{array}{c}\text { ріст } \\
\text { відсутній }\end{array}$ & $\begin{array}{c}\text { ріст } \\
\text { відсутній }\end{array}$ & \\
\hline & 3 & $\begin{array}{c}\text { ріст } \\
\text { відсутній }\end{array}$ & $\begin{array}{c}\text { ріст } \\
\text { відсутній }\end{array}$ & $\begin{array}{c}\text { ріст } \\
\text { відсутній }\end{array}$ & & $\begin{array}{c}\text { ріст } \\
\text { відсутній }\end{array}$ & $\begin{array}{c}\text { ріст } \\
\text { відсутній }\end{array}$ & $\begin{array}{c}\text { ріст } \\
\text { відсутній }\end{array}$ & \\
\hline \multirow{3}{*}{ 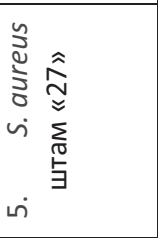 } & 1 & $\begin{array}{c}\text { ріст } \\
\text { відсутній } \\
\end{array}$ & $\begin{array}{c}\text { ріст } \\
\text { відсутній } \\
\end{array}$ & $\begin{array}{c}\text { ріст } \\
\text { відсутній } \\
\end{array}$ & \multirow{3}{*}{$\underbrace{\stackrel{5}{y}}_{0}$} & $\begin{array}{c}\text { ріст } \\
\text { відсутній } \\
\end{array}$ & $\begin{array}{c}\text { ріст } \\
\text { відсутній } \\
\end{array}$ & $\begin{array}{c}\text { ріст } \\
\text { відсутній } \\
\end{array}$ & \multirow{3}{*}{ 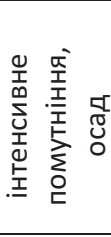 } \\
\hline & 2 & $\begin{array}{c}\text { ріст } \\
\text { відсутній }\end{array}$ & $\begin{array}{c}\text { ріст } \\
\text { відсутній }\end{array}$ & $\begin{array}{c}\text { ріст } \\
\text { відсутній }\end{array}$ & & $\begin{array}{c}\text { ріст } \\
\text { відсутній }\end{array}$ & $\begin{array}{c}\text { ріст } \\
\text { відсутній }\end{array}$ & $\begin{array}{c}\text { ріст } \\
\text { відсутній }\end{array}$ & \\
\hline & 3 & $\begin{array}{c}\text { ріст } \\
\text { відсутній }\end{array}$ & $\begin{array}{c}\text { ріст } \\
\text { відсутній }\end{array}$ & $\begin{array}{c}\text { ріст } \\
\text { відсутній }\end{array}$ & & $\begin{array}{c}\text { ріст } \\
\text { відсутній }\end{array}$ & $\begin{array}{c}\text { ріст } \\
\text { відсутній }\end{array}$ & $\begin{array}{c}\text { ріст } \\
\text { відсутній }\end{array}$ & \\
\hline$\stackrel{n}{\stackrel{0}{\vdots}} \widehat{\hat{\omega}}$ & 1 & $\begin{array}{c}\text { поодинокі } \\
\text { колонії }\end{array}$ & $\begin{array}{c}\text { ріст } \\
\text { відсутній } \\
\end{array}$ & $\begin{array}{c}\text { ріст } \\
\text { відсутній } \\
\end{array}$ & & $\begin{array}{c}\text { помутніння } \\
\text { середовища, ріст (+) }\end{array}$ & $\begin{array}{c}\text { ріст } \\
\text { відсутній } \\
\end{array}$ & $\begin{array}{c}\text { ріст } \\
\text { відсутній } \\
\end{array}$ & $\stackrel{\otimes}{\underline{T}} \underset{T}{\underline{T}}$ \\
\hline v & 2 & $\begin{array}{c}\text { поодинокі } \\
\text { колонії }\end{array}$ & $\begin{array}{c}\text { ріст } \\
\text { відсутній } \\
\end{array}$ & $\begin{array}{c}\text { ріст } \\
\text { відсутній } \\
\end{array}$ & 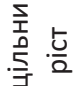 & $\begin{array}{c}\text { помутніння } \\
\text { середовища, ріст (+) }\end{array}$ & $\begin{array}{c}\text { ріст } \\
\text { відсутній } \\
\end{array}$ & $\begin{array}{c}\text { ріст } \\
\text { відсутній } \\
\end{array}$ & 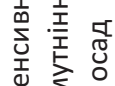 \\
\hline$\dot{\omega}^{\text {与 }}$ & 3 & $\begin{array}{c}\text { поодинокі } \\
\text { колонії }\end{array}$ & $\begin{array}{c}\text { ріст } \\
\text { відсутній }\end{array}$ & $\begin{array}{c}\text { ріст } \\
\text { відсутній }\end{array}$ & & $\begin{array}{c}\text { помутніння } \\
\text { середовища, ріст (+) }\end{array}$ & $\begin{array}{c}\text { ріст } \\
\text { відсутній }\end{array}$ & $\begin{array}{c}\text { ріст } \\
\text { відсутній }\end{array}$ & \\
\hline
\end{tabular}




\begin{tabular}{|c|c|c|c|c|c|c|c|c|c|}
\hline \multirow{3}{*}{ 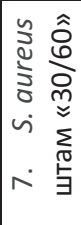 } & 1 & $\begin{array}{c}\text { ріст } \\
\text { відсутній }\end{array}$ & $\begin{array}{c}\text { ріст } \\
\text { відсутній }\end{array}$ & $\begin{array}{c}\text { ріст } \\
\text { відсутній }\end{array}$ & \multirow{3}{*}{ 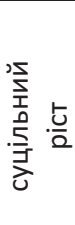 } & $\begin{array}{c}\text { ріст } \\
\text { відсутній }\end{array}$ & $\begin{array}{c}\text { ріст } \\
\text { відсутній }\end{array}$ & $\begin{array}{c}\text { ріст } \\
\text { відсутній }\end{array}$ & \multirow{3}{*}{ 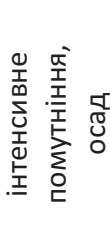 } \\
\hline & 2 & $\begin{array}{c}\text { ріст } \\
\text { відсутній }\end{array}$ & $\begin{array}{c}\text { ріст } \\
\text { відсутній }\end{array}$ & $\begin{array}{c}\text { ріст } \\
\text { відсутній }\end{array}$ & & $\begin{array}{c}\text { ріст } \\
\text { відсутній }\end{array}$ & $\begin{array}{c}\text { ріст } \\
\text { відсутній }\end{array}$ & $\begin{array}{c}\text { ріст } \\
\text { відсутній }\end{array}$ & \\
\hline & 3 & $\begin{array}{c}\text { ріст } \\
\text { відсутній }\end{array}$ & $\begin{array}{c}\text { ріст } \\
\text { відсутній }\end{array}$ & $\begin{array}{c}\text { ріст } \\
\text { відсутній }\end{array}$ & & $\begin{array}{c}\text { ріст } \\
\text { відсутній }\end{array}$ & $\begin{array}{c}\text { ріст } \\
\text { відсутній }\end{array}$ & $\begin{array}{c}\text { ріст } \\
\text { відсутній }\end{array}$ & \\
\hline
\end{tabular}

Таким чином, аналізуючи результати всіх проведених досліджень виявлено польові ізоляти MRSA ( $S$. aureus штами «18», «28» і «30/60»), які були стійкими до дезінфікуючого засобу № 1 за експозиції 30 хв у концентрації 0,25 \%, що було підтверджено ростом культур на твердих і рідких середовищах. За 30 хв експозиції після дії дослідних дезінфектантів у найнижчих концентраціях - 0,25 \% (№ 1) і 0,005 \% (№ 2, № 3).

\title{
В И С Н О В К И
}

1. Виявлено, із 7 польових ізолятів $S$. aureus, одержаних із зразків продуктів, сировини тваринного походження і птахівничої галузі, 6 поліантибіотикорезистентних штамів (в т.ч. 3 - MRSA) з різним ступенем стійкості - від 11,1 до 88,9 \% щодо всіх застосованих антибіотиків та 1 польовий штам $S$. aureus, чутливий до них.

2. Встановлена стійкість 3 польових ізолятів MRSA-штамів золотистого стафілококу до низьких концентрацій дезінфікуючих засобів - 0,25 \% (№1) та 0,05 \% (№2, №3).

3. Передбачається, на основі одержаних результатів, ймовірне формування спільних фенотипічних механізмів стійкості до дії антибактеріальних речовин - антибіотиків і дезінфікуючих засобів, у польових ізолятів $S$. aureus.

Перспективи досліджень передбачають вивчення фенотипічних механізмів формування стійкості до антибактеріальних препаратів і засобів.

\section{STUDY OF STABILITY OF POLYANTIBIOTICOREZISTAN RADIUS $S$. AUREUS TO DISINFECTIVES WITH DIFFERENT ACTIVE SUBSTANCES}

\author{
T. A. Garkavenko ${ }^{1}$, T. G. Kozytska ${ }^{1}$, O. I. Gorbatyuk ${ }^{1}$, V. L. Kovalenko ${ }^{2}$
}

${ }^{1}$ State Research Institute from Laboratory Diagnostics and Veterinary-Sanitary Examination 30, Donetska str., Kiev, 03151, Ukraine

${ }^{2}$ State Scientific Control Institute of Biotechnology and Strains of Microorganisms 30, Donetska str., Kiev, 03151, Ukraine

\section{S U M M A R Y}

S. aureus is one of the main antibiotic-resistant pathogens of bacterial origin, which adapts very quickly to the selective pressure of antibiotic, antiseptic and disinfectants. It is believed that increased stability of staphylococci to antimicrobial agents is associated with uncontrolled application of them in the human population, in the population of animals, the spread of resistant strains between humans and animals, or the transfer of resistant strains from animals to humans (or vice versa) through direct contact and through consumption livestock industry products.

Consequently, the study of phenotypic and genotypic mechanisms for the formation of acquired resistance to antimicrobial agents and the search for their common genetic mechanisms for such anxiety are topical issues of the present.

The article presents research materials to determine the sensitivity of S. aureus field isolates to antibiotics and establishes the level of their resistance to all the drugs used. Based on the data presented, the polyantibiotic resistance of strains of Staphylococcus aureus with a resistance level of 
11.1 to $88.9 \%$ was detected for 18 types of antibiotics used, including 3 strains of MRSA. The materials of the article give data on studies on the effects of some disinfectants on the polyantibiotic resin strain of the pathogen. The article presents the facts that revealed MRSA strains showed particular resistance to experimental disinfectants at certain working concentrations that did not neutralize the pathogen. Detected MRSA strains showed resistance to most antibiotics and were resistant to certain concentrations of disinfectants, which is probably due to the formation of a common phenotypic mechanism of resistance to the action of antibacterial drugs and agents.

Keywords: S. AUREUS, MRSA, STRAINS, ANTIBIOTICS, RESISTANCE, DEZINFECTANTS, FIELD ISOLATES, PHENOTYPIC MECHANISM OF RESISTANCE.

\section{ИЗУЧЕНИЕ УСТОЙЧИВОСТИ ПОЛИАНТИБИОТИКОРЕЗИСТЕНТНЫХ ШТАММОВ $S$. AUREUS К ДЕЗИНФИЦИРУЮЩИМ СРЕДСТВАМ С РАЗНЫМИ ДЕЙСТВУЮЩИМИ ВЕЩЕСТВАМИ}

\section{Т. А. Гаркавенко ${ }^{1}$, Т. Г. Козицкая ${ }^{1}$, О. И. Горбатюк', В. Л. Коваленко ${ }^{2}$}

Государственный научно-исследовательский институт по лабораторной диагностике и ветеринарно-санитарной экспертизе ул. Донецкая, 30, г. Киев, 03151, Украина

Государственный научно-контрольный институт биотехнологии и штаммов микроорганизмов

ул. Донецкая, 30, г. Киев, 03151, Украина

\section{А Н Н О Т А ЦИ Я}

В статье представлены материалы по определению чувствительности полевых изолятов S. aureus к антибиотикам и установлен уровень ихней резистентности относительно всех использованных препаратов. Согласно представленных данных была установлена полиантибиотикорезистентность штаммов золотистого стафилококка на уровне от 11,1 до 88,9 \% относительно 18 видов использованных антибиотиков, в т.ч. и 3 штамма MRSA. B материалах статьи приведены данные исследований по изучению действия некоторых дезинфицирующих средств на полирезистентные штаммы возбудителя. В статье приведены факты того, что выявленные штаммы MRSA проявляли особенную стойкость относительно испытуемых дезинфектантов у определенных их рабочих концентрациях, которые не уничтожали возбудителя. Выявленные MRSA штаммы проявляли резистентность к большинству антибиотиков и были стойкими к воздействию определенных концентраций дезинфицирующих средств, что, возможно, связано с формированием общего фенотипического механизма стойкости к воздействию антибактериальных препаратов и средств.

Ключевые слова: S. AUREUS, MRSA, ШТАММЫ, АНТИБИОТИКИ, РЕЗИСТЕНТНОСТЬ, ДЕЗИНФЕКТАНТЫ, ПОЛЕВЫЕ ИЗОЛЯТЫ, ФЕНОТИПИЧЕСКИЙ МЕХАНИЗМ СТОЙКОСТИ.

\section{Л I T Е P A T У P A}

1. Сидоренко C. B. Молекулярные основы резистентности / С. В. Сидоренко, В. И. Тишков // Успехи биологической химии. - 2004. - В. 44. - С. 263 - 306.

2. Фурсова Н. К. Лекарственная устойчивость микроорганизмов: Учебное пособие / Н. К. Фурсова. - Щелково: ОнтоПринт, 2012. - 86 с.

3. Alp S. Bacterial resistance to antiseptics and disinfectants / S. Alp. // Microbiol. Bul. 2007. - V. 41(1). - P. 155-161. 
4. Gnanadhas D. P. Biocides - resistance, cross-resistance mechanisms and assessment / D. P. Gnanadhas, S. A. Marathe // Expert Opinion on Investigational Drugs. - 2013. - V. 22 (2). - P. 191-206.

5. Fraise A. P. Biocide abuse and antimicrobial resistance-a cause for concern? / A. P. Fraise // J. Antimicrob. Chemother. - 2002. - V. 49 (1). - P. 11 - 12.

6. Волобуєва Л. М. Результати вивчення антибіотикочутливості та антибіотикорезистентності різних видів стафілококів та їх асоціацій з іншими збудниками піодермій / Л. М. Волобуєва // Український медичний альманах. - 2005. - № 4 (8). - С. 46-48.

7. Риженко В. П. Результати вивчення антибіотикочутливості мікроорганізмів, виділених від великої рогатої худоби / В. П. Риженко, Г. Ф. Риженко, О. І. Горбатюк [та ін.]. // Ветеринарна біотехнологія. - Бюл. № 22. - 2013. - С. 467 - 475.

8. Родин В. Б. Перекрестная устойчивость микроорганизмов к антибиотикам, сопряженная с резистентностью к дезінфектантам / В. Б. Родин, Е. Н. Кобзев, Е. В. Детушева [и др.]. - Дезинфекционное дело. - Москва: 2011. - В. 4. - С. 20 - 26.

9. Гренкова T. А. Контроль за устойчивостью микроорганизмов к антибиотикам, антисептикам и дезинфицирующим средствам / Т. А. Гренкова, Е. П. Селькова, М. П. Гусарова [и др.]. // Эпидемиология и вакцинопрофилактика. - № 1 (74). - 2014. - С. 29-33.

10. Алексеева И. Г. Особенности формирования устойчивости условно-патогенных микроорганизмов к дезинфектантам: автор. дис. ... канд. мед. наук. - Нижний Новгород: 2009. $-26 \mathrm{c}$.

11. Tote K. Inhibitory effect of biocides on the viable Masses and matrices of Staphylococcus aureus and Pseudomonas aeruginosa biofilms / K. Tote, D. Horemans, D. Van den Berghe, L. Maes, P. Cos. - 2010. - V. 76. - P. 3135-3142.

12. Дибкова С. М. Наночастинки золота та срібла - ефективні агенти елімінації плазмід антибіотикорезистентності / С. М. Дибкова // Вісник проблем біології та медицини. - 2014 B. 3. - T. 2 (111).- C. 314-318.

13. Визначення чутливості мікроорганізмів до антибактеріальних препаратів: методичні вказівки / Т. О. Гаркавенко, О. М. Неволько, Т. Г. Козицька [та ін.]. - Київ, ДНДІЛДВСЕ, 2015. - 79 с.

14. Методи визначення та оцінки показників безпеки і якості дезінфікуючих, мийнодезінфікуючих засобів, що застосовуються під час виробництва, зберігання, транспортування та реалізації продукції тваринного походження : методичні рекомендації / I. Я. Коцюмбас, О. І. Сергієнко, Л. М. Ковальчик [та ін.]. - Київ, 2010 р. - 152 с.

15. Методы лабораторных исследований и испытаний дезинфекционных средств для оценки их эффективности и безопасности: Руководство Р 4.2. 2643 - 10. - М.: Федеральная служба по надзору в сфере защиты прав потребителей и благополучия человека, 2004. - 302 с. - Библиограф.: С. 126-130; 134-136; 144-147.

16. Довідник санітарно-мікробіологічних методів дослідження харчових продуктів та об’єктів довкілля / В. М. Івченко [та ін.] // Біла Церква, 2004. - 242 с. - Бібліограф.: С. 221240.

\section{References}

1. Sidorenko S. V. Molekuljarnye osnovy rezistentnosti / S. V. Sidorenko, V. I. Tishkov // Uspehi biologicheskoj himii. - 2004. - V. 44. - S. 263 - 306. (in Russian).

2. Fursova N. K. Lekarstvennaja ustojchivost' mikroorganizmov: Uchebnoe posobie / N. K. Fursova. - Shhelkovo: OntoPrint, 2012. - 86 s. (in Russian).

3. Alp S. Bacterial resistance to antiseptics and disinfectants / S. Alp. // Microbiol. Bul. 2007. - V. 41(1). - P. 155-161. 
4. Gnanadhas D. P. Biocides - resistance, cross-resistance mechanisms and assessment / D. P. Gnanadhas, S. A. Marathe // Expert Opinion on Investigational Drugs. - 2013. - V. 22 (2). - P. 191-206.

5. Fraise A. P. Biocide abuse and antimicrobial resistance - a cause for concern? / A. P. Fraise // J. Antimicrob. Chemother. - 2002. - V. 49 (1). - P. $11-12$.

6. Volobuieva L. M. Rezultaty vyvchennia antybiotykochutlyvosti ta antybiotykorezystentnosti riznykh vydiv stafilokokiv ta yikh asotsiatsii z inshymy zbudnykamy piodermii / L. M. Volobuieva // Ukrainskyi medychnyi almanakh. - 2005. - № 4 (8). - S. 46-48. (in Russian).

7. Ryzhenko V. P. Rezultaty vyvchennia antybiotykochutlyvosti mikroorhanizmiv, vydilenykh vid velykoi rohatoi khudoby / V. P. Ryzhenko, H. F. Ryzhenko, O. I. Horbatiuk [ta in.]. // Veterynarna biotekhnolohiia. - Biul. № 22. - 2013. - S. 467 - 475. (in Ukrainian).

8. Rodin V. B. Perekrestnaja ustojchivost' mikroorganizmov k antibiotikam, soprjazhennaja s rezistentnost'ju k dezinfektantam / V. B. Rodin, E. N. Kobzev, E. V. Detusheva [i dr.]. Dezinfekcionnoe delo. - Moskva: 2011. - V. 4. - S. 20 - 26. (in Russian).

9. Grenkova T. A. Kontrol' za ustojchivost'ju mikroorganizmov k antibiotikam, antiseptikam i dezinficirujushhim sredstvam / T. A. Grenkova, E. P. Sel'kova, M. P. Gusarova [i dr.]. // Jepidemiologija i vakcinoprofilaktika. - № 1 (74). - 2014. - S. 29-33. (in Russian).

10. Alekseeva I. G. Osobennosti formirovanija ustojchivosti uslovno-patogennyh mikroorganizmov k dezinfektantam: avtor. dis. ... kand. med. nauk. - Nizhnij Novgorod: 2009. - 26 s. (in Russian).

11. Tote K. Inhibitory effect of biocides on the viable Masses and matrices of Staphylococcus aureus and Pseudomonas aeruginosa biofilms / K. Tote, D. Horemans, D. Van den Berghe, L. Maes, P. Cos. - 2010. - V. 76. - P. 3135-3142.

12. Dy`bkova S. M. Nanochasty`nky`zolota ta sribla - efekty`vni agenty` eliminaciyi plazmid anty 'bioty`korezy`stentnosti / S. M. Dy`bkova // Visny`k problem biologiyi ta medy`cy`ny”. - 2014 - V. 3. - T. 2 (111).- S. 314-318. (in Russian).

13. Vy`znachennya chutly`vosti mikroorganizmiv do anty`bakterial'ny'x preparativ: metody`chni vkazivky` / T. O. Garkavenko, O. M. Nevol `ko, T. G. Kozy`cz`ka [ta in.]. - Ky`yiv, DNDILDVSE, 2015. - $79 \mathrm{~s}$.

14. Metody` vy`znachennya ta ocinky` pokazny`kiv bezpeky`i yakosti dezinfikuyuchy`x, my`jno-dezinfikuyuchy`x zasobiv, shho zastosovuyut`sya pid chas vy`robny`cztva, zberigannya, transportuvannya ta realizaciyi produkciyi tvary`nnogo poxodzhennya : metody'chni rekomendaciyi / I. Ya. Kocyumbas, O. I. Sergiyenko, L. M. Koval`chy`k [ta in.]. - Ky`yiv, 2010 r. - 152 s.

15. Metody laboratornyh issledovanij $\mathrm{i}$ ispytanij dezinfekcionnyh sredstv dlja ocenki ih jeffektivnosti i bezopasnosti: Rukovodstvo R 4.2. 2643 - 10. - M.: Federal'naja sluzhba po nadzoru v sfere zashhity prav potrebitelej i blagopoluchija cheloveka, 2004. - 302 s. - Bibliograf.: S. 126$130 ; 134-136 ; 144-147$.

16. Dovidny`k sanitarno-mikrobiologichny`x metodiv doslidzhennya xarchovy`x produktiv ta ob'yektiv dovkillya / V. M. Ivchenko [ta in.] // Bila Cerkva, 2004. - 242 s. - Bibliograf.: S. 221-240.

Рецензент - О. В. Ложкіна, к. вет. н., зав. науково-дослідним патоморфологічним відділом ДНДІЛДВСЕ. 